RESEARCH ARTICLE

\section{A(M)other Logic (of Love): Languaging the Corporeal Culture of Placental-Chimeric-Maternal Relations}

\author{
Cheryl Lynch-Lawler*
}

*Training and Supervising Psychoanalyst, Saint Louis Psychoanalytic Institute, US

\begin{abstract}
Western culture as it was being established in ancient Greek civilization was erected on a faulty foundation in which consciousness was (in)formed by a series of oppositions housed in hierarchical binaries - nature vs. culture, body vs. mind, feminine vs. masculine, etc. Such bifurcated consciousness poses one aspect of the oppositional pair against the other, rather than as different and non-oppositional poles of a bi-unity. In this system, the body, nature, and the feminine were considered secondary to mind, culture, and the masculine. The maternal-feminine in this system was reduced to mere body and nature and was posed as that against which the (male) philosopher had to assert himself as an autonomous and transcendent subject. Hence, we could say that any alternative logic that would understand the maternal-feminine on its own terms was foreclosed and muted. As a result, the maternal-feminine was discursively rendered as the denigrated other of a faulty hierarchical binary logic. This logic has resulted in a mutilation of the capacity for loving relations with the $(\mathrm{m})$ other, the model for all future loving relations. Due to her erasure as a subject in her own right, she was not able to provide a generative limit; an alternative, to what has become a sacrificial logic (of love). Through languaging of the corporeal culture embodied in both placental-chimericmaternal relations, and differences in engendering between males and females, a path is opened for $a(m)$ other logic (of love) to emerge as difference-in-relation.
\end{abstract}

\section{Keywords}

bi-unity; corporeal culture; speaking corporeal; placental-chimeric relations; a $(m)$ other logic (of love); middle/third space; threshold; ternary logic

\section{Introduction}

We have to discover a language which does not replace the bodily encounter [with the mother] [...] but which can go along with it, words which do not bar the corporeal, but which speak corporeal. (Irigaray, 1991, pp. 43)

Western cultures are experiencing what I refer to as disorders of "thirdness." I understand "thirdness" as an inviolable, mediatory threshold space that both enables and sustains difference-in-unity. In both my clinical practice, as well as my sense of cultural/political trends in the West, I witness an increasing difficulty in sustaining a threshold, a third, a space from which to mediate between differences. It seems urgent that we "leave our logic for another" (Irigaray 2008, 129). For all the seeming multiplicity, it is my contention that hierarchical binary logic of the one and its other continues to inform cultural and personal relations. ${ }^{2}$ This is clearly evident to me when listening to my client's dreams, many of which represent broken, derelict, and missing bridges (Lynch-Lawler, 2020). We need new bridges that can facilitate non- oppositional relations between two. It is in the spirit of rehabilitating thirdness,

\footnotetext{
${ }^{1}$ See Coelho, N. (2015) for a discussion of the concept of thirdness in contemporary psychoanalytic theory.

${ }^{2}$ See Irigaray (1985a;1985b) on the logic of the one and its other. Essentially, she argues that this logic is comprised of a hierarchical binary in which the other of the one is defined in relation to the one, as its complement, opposite or lesser copy, rather than on its own terms.
} 
that I develop the concept of a(m)other logic (of love) which I suggest can be fruitfully elaborated from the corporeal dynamics found within the maternal/fetal dyad, in particular, the placental economy. I posit that $(m)$ other logic as I conceive of it bears within it an alternative model of love as that current which arises within the threshold of mutual exchange between two who are separate yet connected. ${ }^{3}$

The placental economy is exemplary of a mediatory third space given its "relative autonomy...as a system regulating exchanges between the two organisms... [and establishing] a relationship between mother and fetus" that mitigates against fusion (Irigaray, 1993, p. 39). Furthering the notion of the placenta as third space is the current research into biological cell "chimerism" which is described as the "transfer of cells between a pregnant woman and fetus during gestation-and subsequent mingling of transferred cells, or microchimerism" (Kelly, 2012, p. 233).

In developing the corporeal culture of the placental-chimeric economy I hope to free the mother-and fetus-from a cultural fantasy in which the subjectivity of each is seen as submerged in fusional oneness. Additionally, the concept of a(m)other logic (of love) may serve as a way of representing the maternal-feminine as a subject in her own right, birthing her symbolically. For the maternal-feminine arising from the Greek foundations of Western metaphysics has been denied a logic, a language, that is consistent with her corporeal nature-a nature with the capacity for holding the other within without engulfing the other. Rather, in Western culture the womb has remained "unthought in its place of the first sojourn in which we become bodies... denying the mother her generative power" (Irigaray, 1991, p. 41). Western culture was erected on a foundation of symbolic matricide and a return to this foundation is essential to building an understanding of the need for $a(m)$ other logic (of love). As Vaughan (2015) has argued, "denial of the maternal basis [of culture] is responsible in large part for the oppression of women" and if symbolized, maternal relations could create the possibility for imagining an alternative to the purely transactional nature of commodity capitalism" (p. 87). I will return to Vaughan's conception of the "gift economy" further on when elaborating on the mutual exchange inherent in maternal-fetal-chimeric relations.

\section{Symbolic Matricide}

"Give or take a few additions and retractions, our [Western] imaginary still functions in accordance with the schema established through Greek mythologies and tragedies". (Irigaray, 1991, pp. 36)

Maternal-feminine generativity is the unthought ground of Western metaphysics, a metaphysics reflected in ancient Greek mythology. For example, the symbolic burial of the maternal-feminine is rendered in the dynamic found in Aeschylus's Oresteia in which Orestes, inspired by Apollo, murders his mother, Clytemnestra, in retaliation for the murder of his father Agamemnon who had "sacrificed their daughter to conflicts between men, a motive which is often forgotten by the tragedians" (Irigaray, 1991, pp. 37). Orestes becomes mad after the matricide, perhaps a result of persecutory anxiety. ${ }^{4}$ However, there is an even deeper madness playing out as the story unfolds:

When placed on trial for matricide, it is the motherless daughter of Zeus, Athena, who declared Orestes innocent. However, Athena herself is perhaps mad, although it is a madness she cannot begin to know because its roots run prior to her 'birth' from the head of her father, Zeus, and are found in an even prior matricide-that of the mother of Athena, Metis. For, although she does not remember a mother and therefore has no way of symbolizing a relationship to her origin, she was not the motherless daughter that she has come to accept as part of her identity in Greek patriarchal tradition.

As Hesiod tells the tale, it was after the defeat of the Titans, signifying the defeat of

\footnotetext{
${ }^{3}$ The question of love is emerging in feminist love studies as as "an important ethical, social and/or political force" and no longer as a mere accompaniment to issues of identity, sexuality and caring (Ferguson \& Toye, 2017). For example, an entire issue of Hypatia in Winter 2017 (Hypatia 32(1)) was devoted to feminist love studies. See also, (Garcia-Andrade, A. Gunnarasson, L. \& Jonasdottir, A., 2018) on the importance of love for feminist theory.

${ }^{4}$ See Wieland (2000) for an in-depth discussion of the persecutory anxiety resulting from "the return of the repressed [maternal-feminine]." Following Irigaray (1991) she begins with psychic/cultural matricide represented in the Orestia. She goes on to argue that as Western patriarchal societies continue to dissolve, what has been repressed returns with a vengeance, much like the Furies that haunt Orestes.
} 
the pre-Indo-European culture, that Olympian Zeus rapes/seduces Metis, the Titan goddess of Wisdom, whose symbol was the serpent. She becomes pregnant and in an act of usurpation, he swallows her whole...Athena herself is severed from any connection to her origin and becomes the perfect mouthpiece for the emerging patriarchal order. (Lawler, 2011, pp. 17) ${ }^{5}$

Symbolic matricide subsists in the originary discourse of psychoanalysis (Lawler 2011) and remains to a large extent, the unthought ground of Western metaphysics as is evident in the fact that in much of feminist theory the maternal-feminine is noticeably missing (O'Reilly, 2016, p. 185). This founding logic of Western culture as it was imagined in pre-Socratic Greek thought, which has trickled down to current ways of viewing reality and the world, was based upon a false binary in which the living world was severed from and set up as the other of the conceptual. As I have argued (Lynch-Lawler, 2019) the splitting of what had been integral, i.e. nature and culture, body and mind, began to be severed in what has been described as the Axial age occurring roughly between 1500 and 500 BCE. During that era there was a global shift in human consciousness. Self-consciousness began to be reflected in new religious and philosophical thought in China, India, Persia, Judea, and Greece (Jaspers, 1953). In Greece this self-consciousness manifested as an increasing tendency towards human abstraction from the living world in which concepts were privileged over precepts rather than being elaborated from them.

As the living world became the other of the philosophers' musings, the maternal-feminine other became associated with the living world of nature from which the (male) philosopher sought to separate himself. Irigaray and others have seen this movement away from the experiential sense world as it was being developed by these pre-Socratic philosophers as a crossroads where a wrong turn was taken which has proved foundational to Western culture (Irigaray, 2013; Steiner, 1985). For example, Parmenides believed that there were two sources of human knowledge, that provided by sense impressions, which he deemed to be comprised of "delusion and error," and that originating from "pure thinking that takes no account of experience" which he deemed to be the only means by which one could attain knowledge of truth (Steiner, 1985, p. 13). Irigaray (2013) relates this Parmenidean form of logic to a closure of the world in which the "living being as such fails to be" (p. 12). In this logic, a false dichotomy is erected between Being and not-Being which obfuscates the integral dynamic between being and a becoming that is never completed (p. 12). ${ }^{6}$

Pre-Socratic philosophers embedded their own ambivalence regarding their maternal origin within their philosophical conceptions of nature/the body/the maternal-feminine as the denigrated others of the abstracted/conceptual and privileged [male] standard. Their psychology, and the lacunae therein, was taken up into their philosophy and resulted in this wrong turn which has been elaborated in the psychic worlds of individuals steeped in this culture (Irigaray, 2013). Cultural representations are often infused with human error which is encoded and promulgated in such a way as to become the "reality" of a given culture. These faulty cultural configurations are usually relegated to the cultural unconscious where they continue unabated for centuries (Barfield, 1988). ${ }^{7}$ It seems clear that being human comes with the "ability . . . to be mistaken" (Irigaray 2013, p. 21). To conceive, as the preSocratic philosophers did, of the maternal-feminine as a mute substrate conflated with a

${ }^{5}$ See also (Keller, 1986) for an in-depth exegesis of cultural and symbolic matricide as evidenced in the myths of ancient Greece and Mesopotamia.

${ }^{6}$ The splitting of previously integral consciousness is further illustrated within the framework of ancient Greek religion in the interplay between Ouranian sky religion which came to predominate and which is spatial in character, and Chthonic religion which relates more to temporality, not in terms of clock time but in cyclic, rhythmic time more characteristic of living systems. Chthonic ethics understands life and death to be integral aspects of one, repeating cycle, birth-growth-death, whereas Ouranic ethics espouses pairings of contraries. See Wheelwright, (1997) for an in-depth discussion of this aspect of ancient Greek religion. See Cornford (1991) regarding how ancient Greek religion influenced preSocratic philosophy.

${ }^{7}$ Regarding the prospect of an evolution in consciousness, Barfield argues that we must come to grips with our pre-history and yet we cannot understand this pre-history until "we have firmly grasped the fact that the phenomenal world arises from the relation between a conscious and an unconscious and that evolution is the story of the changes that relation has undergone and is undergoing" (Barfield, 1988, p. 136). He argues that what is housed in the unconscious of a given culture is unique to that culture and varies both between cultures, and over time within a given culture. This is pertinent to my inquiry, which will address a question Irigaray has raised as to the particularity of the Western unconscious. 
dispirited nature, was a mistake, a mistake that continues to undermine possibilities for non-oppositional and loving relations.

In the ancient pre-Socratic world view, the maternal-feminine was associated with the chthonic, cyclic, living world and became that against which masculine consciousness affirmed a-faulty?-process of individuation/separation from her. What I refer to as an original, integral, bi-unity of body and mind was severed, with body being represented as the natural other of a disembodied and increasingly analytical-rational mind. A nice illustration of this faulty process is found in Sampson's (2013) analysis of pre-Platonic Greek thought depicted in the works of Homer and Hesiod. She found that the dualism between body and mind, or soma and psyche, that has come to predominate Western culture is culturally bound. For Homer, the body is not thought separately from what it does as a living body:

[T]here cannot be a body, given as natural entity, that is sexed, and that is distinguished clearly from a culturally gendered aspect. If sexual difference were thought of as a way of being in the world, a way of living, this would then be something that permeates the living man and woman. It would be something that fuses and intertwines notions such as nature and culture, body and soul, sex and gender. (Sampson, 2013, pp. 241-42)

What subsequently unfolded in ancient Greek thought posed a striking departure from the biunity of body and mind found in Homer and Hesiod which was prior to the ascendency of the rational mind characteristic of the Axial age in Greece. An unfortunate result of this severing of body/mind was that the maternal-feminine body was relegated to the realm of nature/body and was not represented symbolically on its own terms. Rather the maternal-feminine was imagined as the other of discourse as it emerged in the time of the severing.

In what follows I will offer a possible pathway forward towards the creation of an alternative logic, a(m)other logic (of love) from which to "birth" the maternal feminine on her own terms and in her own language and logic. I posit that $(m)$ other logic will open a doorway into another dimension of love - love that is non-sacrificial ${ }^{8}$ and is based upon difference-in-unity as it is exemplified in the mutual exchanges that occur in the space of placental-chimeric relation between mother and fetus.

A conceptualization/symbolization of the maternal-feminine was foreclosed or, we might more accurately say, interred, at the beginning of Western culture as elaborated by preSocratic Greek philosophers. With the maternal-feminine cast as the foundational outside of their conceptual framework, it is necessary to theoretically exhume the body of the mother, hence creating a space from which she can accede to a language/logic of her own. ${ }^{9}$ Said otherwise, "we need to re-chart the maternal as a terrain of body and word" (Walker, 1998, p.

\footnotetext{
${ }^{8}$ For an in-depth analysis of sacrificial love see Lawler-Lynch (2016).

${ }^{9}$ I will argue that in order for this to be possible, we will need to transmute what has been described as a prosthetic/sacrificial model of intimacy (Lawler-Lynch, 2016) into a model grounded in maternalfeminine difference "actualized" in logical discourse, creating an opening in the cultural register that can move us beyond a phallogocentric worldview of the privileged "One" and its other, which amounts to one. Rather than being set up against the other, I will show how this process can move us beyond oppositional complementarity, towards relating/loving that is grounded in a difference than cannot be reduced to the equation $(A$, non- $A)$.

Apropos to the capacity to think difference beyond binary logic is the work of Basarab Nicolescu. Drawing upon the work of French physicist, Stephane Lupasco, Nicolescu has theorized differing levels of Reality manifesting via a ternary process. According to Nicolescu, there is a dance between "actualization" and "potentialization." When something is actualized, other possibilities are repressed and placed in a state of potentialization in which is housed the "memorization of what-has-not-yet-beenmanifested" (Nicolescu, 2014, p. 128). I argue that the maternal-feminine is the repressed potential of Western culture which can be recovered, re-membered and "actualized" via a ternary process which I locate in the corporeality of the placental relation as emblematic of the third term.
} 
140), that is to say, her own body and word, and not as she has been conceived heretofore. ${ }^{10}$ To understand the urgency of the need for $a(m)$ other logic (of love) it will be useful to first provide a brief sketch of the cultural and intrapsychic results of the dereliction of maternalfeminine subjectivity.

\section{Subterranean Longings: Maternal-Feminine Abjection and her Abject Others}

Thus we might wonder whether certain properties attributed to the unconscious may not, in part, be ascribed to the female sex, which is censured by the logic of consciousness. Whether the feminine has an unconscious or whether it is the unconscious. (Irigaray, 1985, pp. 73)

As the bi-unity of body and mind was superceded by a binary separation of these two properties, the maternal-feminine, the divine-feminine, and nature became fused (Irigaray, 2013) and the constructor of this new logic bequeathed his body, his nature, to her, as his mind formed a logic antagonistic to those aspects of himself-his body, his nature - now coded "feminine" and "nature." He buried his physical fertility and wholeness in a deathdealing logic. His own corporeal existence was exported to the maternal-feminine whose role it became to house all of embodiment. As the master of logos says to his disciple:

[y]our body, your flesh, your heart are very little in the face of its truth. And it is fitting that your eyes and your ears perceive the real [world] in accordance with the words already pronounced about it. It is through a logical net that you must approach and dominate the whole and even yourself. (Irigaray, 2013, p. 55)

The master logician severed the bi-unity of his living body/mind in this process of inaugurating a logic grounded in a false hierarchical binary. But here is the dilemma: because the maternal-feminine in this logical system was designated as the site of body/nature/heart, it is she which guarantees his wholeness. She becomes a "prosthetic device" (Lawler-Lynch, 2016), a "maternal function" (Irigaray, 1991) on whom he is dependent as the guarantor of what he has disavowed of himself. Perhaps, we may wonder, if this is the reason there is so much obsessive emphasis placed on controlling women's bodies?

From a psychoanalytic perspective, the "subjectivity of a man is structured by differentiating himself from the mother-nature; it is constructed to a great extent not only in spite of her but against her" (Irigaray, 2004, pp. 68). Western philosophical views of the maternal as his other, operate to soften the pain the male experiences as he differentiates himself from the mother who embodied his origin-was his originary you. Psychic "matricide," rather than being an "empirical reality" [occurs] at the psychical level, in wishful fantasy, as a way of organizing the self as it is understood-cum-imagined" (Stone, 2012, pp. 43). The male child's task is doubly complicated given that not only must he, like the female child, differentiate from the mother if he is to accede to independent subjectivity, but he has the added task of negotiating what it means that he is not able to engender in the same way as his mother. ${ }^{11}$ He will have to "protect himself from the mystery, indeed the abyss, that his origin, his mother,

10 The task of conceiving the maternal in body and words places this essay within the feminist debate between poststructuralist theorists such as Butler who wish to overcome biological determinism by reducing the body to an inert tabula rasa for the inscriptions of social construction, and those, like Grosz, who argue against this notion of the biological body as passive matter and instead insist on the co-emergence of the social and the biological. However, as Gunnarsson (2014) has argued, even Grosz falls into a poststructuralist reductionism in that she essentially undoes the inherent limiting quality of the natural by celebrating the absolute indeterminacy of nature. Gunnarsson's own position, and one which accords with the spirit of this essay, opens onto a non-reductionistic view in which nature sets real parameters as to what is possible for human nature. It is within the dialectic between nature and culture; between the body and discourse, that real human freedom is found and as I endeavor to "speak corporeal" in the body of this essay it will be from within the middle/third space between two separate yet inseparable domains: body and word; nature and culture.

11 To add to the difficulty that a male child suffers in negotiating procreative differences in generativity with the mother, there is relatively little emphasis on male contributions to procreation which, I understand as one of the costs to male inheritors of a culture that abstracts the [male] mind from body. There is no human life created without the contribution of sperm and yet little boys are not educated to understand, and therefore value, themselves as potential procreative partners in the reproduction of human life. Using clinical case material as an example, I write about the challenges faced by male children in their struggle to maintain a positive connection with the mother while also forging positive identifications with the corporeal logic of their own bodily capacities. See Lynch-Lawler, (Forthcoming, June 2021). 
represents for him" (Irigaray, 2004, pp. 90). One of the methods deployed intra-psychically as well as culturally, to distance/separate/sever the masculine self from the maternalfeminine is the denigration of the mother. This maternal denigration is evidenced in the clinical practices of psychoanalysts (Birksted-Breen, 1996; Elise, 1997; Lawler-Lynch, 2011; Marcus, 2004). Feminism notwithstanding, analyses of both men and women reveal a denigrated image of the maternal-feminine (Lawler-Lynch, 2011) making motherhood studies and maternal subjectivity urgent and key concerns for contemporary feminism. What we find, in the place of the maternal-as-subject-in-her-own-right are:

twin poles of idealization and a defensive scorn and denigration of the maternalfeminine [and] ... ultimately, she who must to some degree be left, or more forcefully abjected or killed off, in order that 'the subject' [...] can emerge unscathed... [with the good mother functioning as she who] continued to love us despite our destructive attacks. (Baraitser, 2009, pp. 5)

How are we to understand culturally bound pressures that perpetuate psychic matricide in which mothers themselves are often complicit, due to their, often unconscious, identification with a desubjectivized, self- sacrificing, notion of a "good" mother?

According to Rose (1996), the mother is asked to bear a "catastrophe" of identity:

This felt catastrophe is simply the fact that there is an unconscious, that we cannot fully know [...] either the other or ourselves [...] We try to limit the damage, we protect ourselves from the felt danger, by fleshing out our anxiety, giving the zone of anguish a name: femininity, nonlanguage, body. But the name we give it before all others, the one we really hold answerable for it, is the mother. (Rose, 1996, pp. 421) ${ }^{12}$

Here the continuity between Western philosophical beginnings which placed the maternalfeminine-body outside the realm of what could be known, and ongoing fantasies about the mother as the denigrated other and bearer of the vast unknown-unconscious are quite evident. As was suggested above, given the burial of the maternal-feminine in the cultural unconscious of the West, subjects in that culture often suffer persecutory anxiety as a result of unconscious guilt and fear of the return of the mother who has been repressed (Wieland, 2000). Hence, due to these cultural dynamics, real mothers seem even more ominous when we consciously and unconsciously think of them as the reservoir of the great unknown-the emblem of the mystery that haunts every human being-the unknown-other-within-our unconscious? ${ }^{13}$ Further, what does it do to mothers to have to "bear" this projection? Again, Rose comments, "if mothers know anything - to give them back their subjectivity in the matter for a moment - it is the travesty of that projection" (Rose, 1996, pp. 421). ${ }^{14}$

\section{The Dawn of $\boldsymbol{A}(\boldsymbol{m})$ other Logic: Psychoanalytic Intersubjective Theory and the Maternal-Feminine as a "Lawful" Third}

Intersubjectivity theory is a more recent evolution of psychoanalytic theory which involves an attempt to theorize two subjects. Intersubjective theory has its earliest roots in the observation of mothers and infants through which the concept of "potential/transitional space" was theorized by Winnicott (1971). The concept of potential space as understood by Winni-

\footnotetext{
12 Likewise, Ferguson (2017) argues that affect in cultures steeped in commodity capitalism, is structured by a "foundational fantasy" essentializing the subject as an isolated and autonomous consumer in competition with the other who is denigrated. According to Ferguson, it is the mother in these societies who is asked to bear the brunt of negative affect for the other. She is the denigrated other par excellence.

${ }^{13}$ We might also wonder what the Western unconscious would become if we were to remove the mother as a container for its refuse but that is beyond the scope of this paper,

${ }^{14}$ We in the West might wonder about our complicity in the cultural lack of maternal subjectivity, given our cultural and personal fantasies that cast the maternal/fetal relationship as being one of fusion with an all-powerful mother (nature). It is understandable how she is subsequently posed as that against whom we must struggle, even to the point of psychic matricide, if we are to claim a bit of autonomy for ourselves. The evidence is there in clinical practice that the unconscious internalizations of our cultural fantasies about the maternal-feminine as simultaneously, nothing but a denigrated function, and as an all-powerful creature holding life and death in her hands, has profound effects on maternal self-esteem. Her capacity to gestate life in the flesh gets subverted as she is required to also carry our misguided and culturally driven fantasies about the maternal in her head, in her sense of herself as a womanmother. This takes a huge psychic toll on actual mothers, often leaving them with little psychic-emotional bandwidth with which to nurture their own being for themselves.
} 
cott represents neither the inner world of infant nor that of the mother, nor does it represent the external world. Rather the concept of potential space designates an intermediate and shared realm between mother and infant, a realm that is co-created in the process of playing, of their interplay. The creation of this space is crucial as the infant begins to differentiate the me from the not me, and optimally, this potential space happens only in relation to a feeling of confidence on the part of the baby... [with] the cultural life of the individual [determined by] the fate of the potential space between any one baby and the human (and therefore fallible) mother-figure who is essentially adaptive because of love. (Winnicott, 1971, p. 100)

This theory has been borne out through decades of clinical work with mothers and infants indicating the necessity of "good enough" maternal attunement to the needs of the infant as they negotiate increasing awareness of maternal separateness and autonomy that is beyond the infant's omnipotent control. The concept of a potential or third space as a feature of maternal/infant relations has now become a clinically verified aspect of psychoanalytic canon and has more recently been extended to the space of the clinical encounter between analyst and client through the work of Ogden and others. ${ }^{15}$

The emphasis on the importance of maternal relations in psychoanalytic theory places greater emphasis on early childhood relations in contrast to the Oedipal theory which began with Freud and was elaborated by Lacan. As indicated above, one of the concepts to be recast within intersubjective theorizing is that of the third term. In traditional psychoanalytic theory the "third term" involved the paternal function as that which forged a necessary intervention into the otherwise "fusional" oneness of the mother/child dyad. Lacan extended the notion of the third term to involve, not just the actual father, but the mother's desire, which extended the mother's attention beyond that of her primary preoccupation with the child and which guaranteed the child's eventual separation and differentiation from what was then theorized as an originary fusion with an amorphous maternal object (Lacan, 1975). However, the idea of an original unity or fusion is a retroactively conceived fantasy devised to deny the alterity of the originary you-the maternal-feminine-as existing separately and in its own right, from the beginning (Irigaray, 2004, 1993; Lawler-Lynch, 2011).

Building on and integrating Winnicott's concept of "potential space" (1971) and Sandler's (2002) concept of nonlinear "rhythmicity" which he located in the "nascent or primordial third" between mother and infant, Benjamin (2005) elaborates the idea of the primordial third as housing "the principle of the earliest exchange of gestures between mother and child in the relationship that has been called oneness" (p. 39). However, this theorized oneness is actually a form of thirdness which Benjamin refers to as "the one in the third," given the "mutual accommodation that underlies it" (pp. 40). This primordial third originates within the intersubjective realm between mother and child as that process/space in which the two cocreate an intermediate realm with its own "music [...] mediated by a rule or pattern or set of expectancies [...] [which] both [mother and child] can modify" (p. 40).

The rhythmicity and mutual exchange that characterize the primordial third that develops in the potential space between mother and infant, is an early form of "lawful, mutually regulating interaction" within which is overcome the necessity for the intervention of the paternal third term of traditional psychoanalytic theorizing to rescue the infant from a so-called fusional oneness with an engulfing maternal function (Benjamin, 2005, pp. 40). In the concept of the primordial third we gain footing for the recognition of two subjects, mother and infant, there from the beginning. From this conceptual footing, we may begin to disinter the maternalfeminine from the subterranean depths of the Western unconscious. However, it is only a conceptual and still precarious footing. Its cultural elaboration is contingent on the mother's capacity to both recognize and engage the infant's need and nascent subjectivity, while also maintaining her own personal integrity, without succumbing unconsciously, either to the denigration inherent in a culturally-inscribed role as a mere need-gratifying function, or that found in the role of the all-powerful, engulfing monster-mother lying in the repressed of our unconscious.

If mothers are not able to fluctuate between the needs of the other and a solid sense of their own subjectivity, if individually, a mother's sense of self is shaky or absorbed into a needfulfilling function, then she may fall into the "kill or be killed" sacrificial logic. If it is in fact the case that "the separate yet recognizing subjectivity of the mother [...] becomes the most precious thing, which is love coming from an other person" (Benjamin, 2005, pp. 52), then it is

${ }^{15}$ See Ogden $(2004 ; 1994)$ and Coelho (2015). 
essential that she, the love-bestowing mother must be a subject-in-her-own-right. Further, given that we all make cross-sex/gender, conscious and unconscious identifications, if our mother's self-concept is limited to that of a need-fulfilling function, existing to enable the individuation of the other, then the precious gift that is the love from a viable, self-respecting (m)other will be nullified at the outset. Further, our identification with her denigration determines our subsequent love relations. In such relations, there will be instilled the sadomasochistic dance between the denigrated object and the subject. ${ }^{16} \mathrm{~A}$ sacrificial model of relationship is merely the logical extension of early Greek philosophy and does not provide for a mutual/middle space of co-becoming-in-love-between-two.

Thus far, I have focused on the culture as it relates to maternal subjectivity and intersubjectivity. However, maternal subjectivity involves the bi-unity of the nature/culture of the maternal-feminine. In the following section I focus on the consubstantial nature of the maternal body/culture before elaborating the nature/culture of placental-chimeric-maternal relations.

\section{Languaging the Corporeal Culture}

[The] task is to cultivate this original relation to the other without letting it regress to a simple natural state, to raise it from the immediate status to a mediated relationship that requires recognition of the transcendence of the other, on a level of the senses as well as the mind. (Irigaray, 2004, pp. 91)

Along with a re-conceptualization of the psychodynamics underpinning the concept of the maternal-feminine in Western culture, the maternal-feminine body must also be re-thought and (re)membered in language. The maternal body has been misrecognized and objectified in terms of its reproductive functionality with the personhood of the mother secondary to her role as (re)producer. Reproduction has been cast in instrumentalist terms with the female body seen as a production machine (Plumwood, 1993). However, both men and women partake of both nature and culture, and both have a role to play in reproduction. How do we re-think reproduction in non-dualist ways for each sex, in which "the body and agency are not split" (Plumwood, 1993, pp. 38) and in which reproduction/engendering is re-cast as having both culture and nature that are thought together, as a bi-unity? Is it possible to return to the living body of the ancient pre-Socratic Greek imagination in which body and mind were not discursively severed and begin to think the corporeal? ${ }^{17}$

In an effort to think the corporeal, it is important to note that "biological and material strata are not ontologically distinct from the conceptual level" but are unified in a relationship of coemergence (Gunnarsson, 2014, pp.27). The relationship of nature and culture is one of "consubstantiality" (Kirby, 2008) in which nature is already culture with a language of its own. As human beings we occupy the ternary threshold, "a fault line that runs throughout all of human nature" between the "radical disjunction/inseparability" of nature and culture (Kirby, 2008, pp. 233-234).

What would it mean to birth the maternal-feminine from within the context of the bi-unity of

\footnotetext{
${ }^{16}$ What I have discovered over the past thirty years in psychotherapeutic practice is that both men and women in relationships, regardless of whether homosexual or heterosexual pairings, vacillate between poles of abjected/privileged and sadistic/masochistic. This is a relational paradigm that is quite common and I trace it to the denigrated maternal-feminine with which both sexes identify. In the norm of crosssex/gender identifications, one usually predominates - is more conscious, while the other remains unconscious. We can see how these identifications play out in their relational difficulties and dynamics.

${ }^{17}$ Freya Mathews (1989) also argues for a unity of body and mind from a Spinozist perspective in which body, or what Spinoza refers to as ideatum, and mind, or what Spinoza calls idea, are two attributes of the same substance. The way she describes it, bodies are formed "geometrodynamically" via the folding and curvature of space into itself. "This folding or curving is an internal limitation or bounding 'modification' - of pure extension" (7). Further, "[t]o every body there corresponds a mind, and the mind is the 'reflection' of the body: the mind is the idea of which the body is the ideatum...the mind is the 'reflection within the order of ideae, of a body which belongs to the order of ideata...[which] follows straightforwardly from the fact that idea and ideatum are just manifestations of the very same mode of substance" (7). These two modes, that of idea and that of extension, are two attributes of the same substance expressed and comprehended in two different ways. There is a unity between body/extension and mind/idea. Here again is a bi-unity of body and mind.
} 
her living body/culture? How might we conceive of our differentiation from a living, consubstantial maternal-feminine as differentiation-within-unity, a differentiation-within-unity that sustains connection even as it facilitates differentiation?

Following Irigaray (2004) I begin to conceive an embodied concept of the maternalfeminine, as a living bi-unity by elaborating from the reality that places each of us in a particular relation to her body, i.e., as those whose potential it is to procreate as she doesfemales-and those whose potential it is to procreate differently from her-males. This determinative difference, which is based on non-oppositional, non-hierarchical and asymmetrical difference qua difference ${ }^{18}$ is that, as earlier discussed in more detail, which was muted by the creation stories/philosophical premises of the ancient Greeks who conjured the birth of Athena as issuing from the head of Zeus after he had swallowed her mother, the pregnant Metis. As previously noted, rather than elaborating difference-in-connection-withthe-maternal, the Greek philosophers instead cast her outside discourse and language as a mute body-receptacle with no place, no language, and therefore no ability to provide a differentiating limit to their logic. With the intention of contributing to the need for a limitation to a hierarchical binary logic of the one and its other I have conjured the concept of $a(m)$ other logic (of love). Without this limit, that of $a(m)$ other logic, these early philosophers were haunted by a sense of painful nostalgia for all that was buried in the archaeological layers of their discourse. ${ }^{19}$

A conception of difference founded on a(m)other logic (of love) asks that we think and language a different relation to the reality of embodiment emerging from of a culture of corporeal relations. Rendering the corporeal symbolically will also "allow the male subject to alter his relationship to the female other, who will then no longer be reducible to the natural universe from which he must separate in order to assert and individualize himself, thus nullifying her to a certain extent" (Irigaray, 2004, p. 91). What Irigaray refers to as sexuate identity understands identity as relational. Relational identity creates "different bridges" within the consubstantial unity of body and culture of males and females whose ways of engendering are different (Irigaray, 2004, pp. 177). ${ }^{20}$

\section{To Begin at the Beginning: Languaging Placental-Chimeric Logic}

Irigaray (1993) first introduced the concept of the "placental relation" as a third/mediating space in her interview with biologist, Helene Rouch who specialized in maternal/fetal relations. ${ }^{21}$ In that interview, Rouch began with a description of the formation of the placenta as the creation of the embryo which, while becoming attached to the uterus, remains separate from it. The placenta mediates the relation between the mother and the fetus so that there is never a fusion of maternal and embryonic tissues" [while also] regulating exchanges between the two organisms [and] modifying the maternal metabolism: transforming, storing and redistributing maternal substances for both her and the fetus' benefit [...] [emphasis added] ensuring growth of the one in the body of the other". (Irigaray, 1993, pp. 39)

\footnotetext{
${ }^{18}$ The bi-unity of body and mind will be different for men and women when it is freed from the logic that severs body from mind, as it will no longer be grounded in a false hierarchical binary that arbitrarily attributes some attributes to the "feminine" and some to the "masculine and then forces these attributes onto an oppositional, false sexual symmetry." Difference is not binary, nor is it symmetrical. Genuine difference is asymmetrical. If we are able to re-open a ternary space in which to think the corporeality of embodied beings, we cannot yet know how that might be elaborated. However, when thought as a biunity, it will be elaborated from the living body and not merely a disembodied conceptual fantasy.

19 See Lynch-Lawler (2019) on Plato's attempt to mitigate the painful nostalgia expressed by the philosophers in the Timaeus regarding the loss of chthonic-participatory consciousness. See also, Irigaray (2013) in which she describes the philosopher's nostalgia for his lost beginnings. For more on the philosopher's obsessive nostalgia for beginnings prior to beginnings see Plato's Timaeus (Plato) especially the section on the chora.

20 It is here that Irigaray's careful distinction between sexual and sexuate sometimes gets lost in translation. Sexuate difference represents Irigaray's attempt to think identity and not the sex act. "This distinction helps to clarify Irigaray's focus on male/female relationships, which does not necessarily entail heterosexuality" (Bostic, 606).

${ }^{21}$ Since Irigaray's initial formulation, there have been a few attempts on the part of feminist theorists to think further about the usefulness of this concept, particularly as it relates to a reconceptualization of subjectivity. See (Fannin 2014; Jones 2011; Jordan 2017; Oliver 1998; Schwab 1994).
} 
This fetal relation is characterized as having an "almost ethical character" (Irigaray, 1993, p. 41).

Essentially, it provides a model for an even more "primordial", primordial third as a mediating term between mother and child. Actual placental dynamics renders the traditional conception of an original fusion of mother and fetus pure fantasy. The maternal relation is not one from which one must extricate oneself, but one which has a logic of mediation between two from the beginning. Placental logic works to undo the-false-requirement of the paternal as the necessary third term as an intervention into an otherwise fusional psychosis. This "differentiation between the mother's self and the other of the child, and vice versa, is in place well before it's given meaning in and by language" (Irigaray, 1993, p. 42). It is stunning that there has been so little theoretical attention given to the role of the placenta.

Coming back around to the beginning - to originary matricide-we might observe how the mother's (and the fetus') subjectivity are disavowed by the general lack of interest in conceptualizing this corporeal relation. Our cultural fantasies of mother/fetal fusion continue to predominate and may promulgate the seeming necessity for drastic measures needed to become an autonomous self-itself a fiction. If we falsely conceive maternal/fetal and maternal/child relations as one of primordial fusion, rather than primordial thirdness, then it requires a herculean task to separate from merger with an all-encompassing non-subject: the mother. For, in essence, we are attempting to separate from a fiction. However, our actual maternal relations are differentiated at the outset and yet have not been articulated so that their reality can be represented symbolically in language. This essay is an attempt to begin that process of speaking the corporeal reality of maternal relations into cultural discourse such that we may begin to re-think difference-in-connection, and birth $a(m)$ other, non-sacrificial, logic (of love) relations.

\section{Chimeric Inter-Subjectivity: The Mother and Her Others}

The female body engenders with respect for difference, the patriarchal social body constructs itself hierarchically, excluding difference. (Irigaray, 1993, pp. 45)

The basis of my argument thus far is founded upon my premise that the corporeal is already cultured and that our discourse, rather that languaging corporeal culture has misrepresented and perverted that culture by denying the difference inherent within it from the beginning. Instead we have inherited a disembodied, abstracted and false logic of hierarchical binaries. Now I want to further elaborate how actual corporeal relations, beginning in maternal/fetal relations provide a portal into another world view and another way of relating as co-becomingsubjects-in-loving-connection. As I stated at the outset, this is represented corporeally by one of the most exciting trends in the biological study of maternal/fetal relations, that of "chimeric" relations between mother and fetus, referred to as "chimerism." Chimerism is defined as "the intermingling of cells from two or more genetically distinct organisms" (Kelly, 2012, pp. 234). The process of cell migration from and to mother and fetus helps to deconstruct reductionist notions of either fusional oneness or absolute subjectival hegemony of the separative self. ${ }^{22}$

The intermingling of maternal and fetal cells that occurs in chimerism provides a corporeal logic "that runs counter to biological, political and social understandings of selves as individuated, discrete and purely self" and yet the study of this process has been relegated to the margins of biology (Kelly, 2012, pp. 234-235). Why? Is the cultural fantasy of a fusional oneness, grounded in a false binary that denies original difference, so entrenched that actual biological data are eclipsed? With regard to maternal-fetal relations, the research has tended to skew the relational conceptualization that arises from placental-chimeric culture in favor of theories that sustain either the erasure of two subjects as in the theoretical delusion of fusional oneness, or that espouse a theory of completely separate subjects with the "personhood" of the fetus often taking priority, ${ }^{23}$ in a relationship of conflict-kill or be killed. Yet, in grounding theory in corporeal culture, in the reality of what occurs in the placental-

\footnotetext{
22 See Martin (2010) for an interesting discussion regarding the ways in which research into biological chimeric relations is being extended into the creation of new metaphors for the understanding of geopolitical relations.

${ }^{23}$ The mother's subjectivity is often eclipsed in current debates over reproductive rights in which the nascent subjectivity of the fetus is privileged and is often portrayed as a "free-floating and independent entity" (Fannin 2014) with the mother as a mere receptacle.
} 
chimeric exchange between mother and fetus, we find a model for relationality in which subjectivity is both interdependent and distinguishable, and, usually mutually beneficial. In fact, studies have shown the health benefits to the mother when fetal cells are found to migrate to various organ systems where they have a therapeutic effect (Kelly, 2012). The intersubjective relationality represented in the process of gestational chimeric cell transfer has implications for rethinking maternal subjectivity in connection with difference, the relational difference that emerges in the consubstantial field of nature and culture that we are.

I suggest that in speaking chimeric, in languaging the placental-chimeric relation, we can further a non-matricidal model for the conceptual birthing of the maternal-feminine, given that it places the mother as a partner, as a subject, who both gives and receives, from the beginning. The permeable yet distinguishable boundaries set within placental-chimeric relations allow for the developing fetuses to bring their own gifts to the $(\mathrm{m})$ other-that of chimeric cells that are often therapeutic to the mother, often enhancing her immune response far into the future. If this placental/chimeric relation is symbolized, is languaged, then the mutuality inherent in this originary exchange between mother and fetus could help to mitigate the tendency, especially for males, to reach for autonomy in opposition to the mother. Rather, languaging the primordial, mutual exchange that defines placental-chimeric relations undercuts any notion of a separate self in opposition. Clearly, there are already two subjects, from the beginning, each with gifts to give.

\section{Mutual Gifting: Towards A(m)other Logic (of love)}

What we find in chimeric relations is the mutual gift-giving between two who are intermingling-interdependencies-within-difference from the beginning. There is a physiological reality, a corporeal culture encoded in this relation that embodies non-oppositional logic of selves that are separate yet interconnected. The corporeal logic found in the maternalplacental-chimeric relation extends to the prenatal sojourn that Vaughan (2015) describes as "nurturing intersubjectivity" between mother and infant (p. 265). Here she makes a crucial distinction between capitalist "market logic" based on quid pro quo exchange, in which the giver gives and then expects reciprocity, and what she refers to as "unilateral giving" characteristic of the relationship between mothers and infants which "is the basis, the first move, the opening gambit of communication" in which the giver satisfies the other's needs without placing a reciprocal obligation on them (pp. 54). In this initial asymmetry between mother and infant, in which the mother's response to the infant's needs provides the opening gambit, there is inaugurated "much mutual responsiveness [which] is not an exchange of equivalents... Rather it is turn-taking, i.e. alternately giving and receiving" (pp. 55). When the original model of the gift economy, that of nurturing intersubjectivity between mothers and infants, is forgotten, is left unsymbolized, it is subject to the perversion of quid pro quo exchange.

Sacrificial logic in the West is both matricidal and "bodycidal," especially for males, whose embodied being is disavowed by its logic (Irigaray, 2013). If we are to transmute the incoherence and lack of meaningful human freedom lodged within matricidal logic then the logic of mutual gift-giving found in placental-chimeric relations may provide a pathway towards what I have referred to as $a(m)$ other logic (of love). The mutual gifting inherent in this relation, when symbolized, has the potential to subvert oppositional logic by recalling the primordial model of placental third space. Placental third space enables interconnected, intersubjective exchange, including chimeric cells, while also safeguarding the difference between two. While the mother gives the gift of life, she is also the recipient of the gift of chimeric cells as a result of placental "oversight." In this logic, the mother is already distinguishable a self-inconnection, and as a receiver of chimeric cells. For the male child who must negotiate his procreative difference while at the same time individuating from the maternal, this acknowledgement and appreciation for the chimeric gift he has already given, even in the process of being given his life, can help to assuage a feeling of inferiority that sometimes accompanies his recognition that he does not share the capacity to gestate life internally as his mother. The primordial third is well established in the placental-chimeric relation, as well as, I would argue, a nascent capacity to love within difference. The morphological signature is written in the flesh of mother and fetus from the beginning and merits languaging if we are to elaborate a culture based not on oppositional quid pro quo but, on a(m)other model of intersubjective gifting and (of love). Further, this corporeal logic can help to alleviate the potential for womb envy that often accompanies the self -differentiating process for males 
(Bayne, 2011; Kittay, 1984a, 1984b; Lynch-Lawler, forthcoming, June 2021). In symbolizing placental-chimeric logic, he is able to view himself as not the merely passive recipient of her gift-giving but an active gift-giver from the beginning.

In Sandoval's (2000) notion of a "hermeneutic of love" she seeks a mutual transformation between world and self in an approach that integrates love within a concept of "third-space." She theorizes third space as a place within which is designated an interstitial realm between self and world in which something new can "become." This "something new", Sandoval claims, is potentially "revolutionary."

Resonant with Sandoval's hermeneutic of love as middle/third space is Irigaray's concept of love which places the emphasis on the intersubjective, middle ground which is based on the limit set by sexuate difference. "Sexuate difference [...] is [...] the place where the first articulation between nature and culture takes place and has to be elaborated" in a culture that is built on "respect for the other" (Irigaray, 2008, pp. 132). ${ }^{24}$ Roberts (2017) finds that Irigaray's "reimagining subjectivity as sexuate" [provides the basis for her] philosophical refiguring of love as an intermediary" (p. 69). In her reading of Irigaray, it is only in establishing sexuate difference that we, as a culture, are able to transmute a culture of narcissism into a culture capable of loving relations. Sexuate difference represents the middle space in Irigaray's attempt to think identity and should not be confused with the sexual nor with the sex act.

For Irigaray, in order to beckon forth a new world, it is crucial for us to reimagine social relations not through the lens of our sexual orientation, but through the lens of love between women and men as is found in the cultural arena (Bostic, 2002). For Irigaray, this sexuate difference is grounded in the differences embodied in one's corporeal relation to engendering. Irigaray challenges us to interrogate the logical structures that perpetuate a "split between body and culture and, moreover, [to] refigure our relations with the maternal body as the origin of life" (Roberts, 2017, pp. 70). For Irigaray, this involves bringing language to the difference found within corporeal relations as already encultured.

Two levels of differentiation are embodied in corporeal culture, that of primordial difference embodied in placental-chimeric relations, and difference in engendering which is a part of sexuate difference. Both have been largely unelaborated in cultural discourse. I suggest that the corporeal logic of placental-chimeric-maternal relations and the middle-space of difference in engendering, together provide the primordial foundation from which to re-think the middle space of love between two genders in the cultural arena. Because our current cultural discourse is a perversion of the reality of the consubstantiality of nature and culture, we must spiral back around this "developmental illness," revisit our beginning, and create a new discourse that is isomorphic with the reality of our actual, corporeal culture. There is no culture that can exist without nature and to think otherwise leads to the most aberrant form of logical incoherence, hence the "wrong turn" from which we have yet to recover. It is in this spiraling movement that we are able to (re)member the maternal-feminine and create an opening for $a(m)$ other logic (of love) that enables difference-in-relation. (Re)membering the mother guarantees a limit to narcissistic relations through the opening of an intermediate middle space between two who are different yet in relation. In this space a(m)other logic (of love) can emerge.

\section{Conclusion}

I have pointed to the connection between our love relations with our first love, the originary you (Irigaray, 2004, p. 68), as setting the parameters within which all future love relations are lived. As a non-appropriative model, placental-chimeric relations beckon us toward a new way of conceiving both ethics and love as co-occurring within a field of difference-in-relation. Our primordial love-relationship with the maternal other of our origins, provides a foundation for all future love-relations. Given this, it is essential that we re-conceptualize that lovingrelation in a manner that departs from the reality of non-fusional dynamics between two, separate yet inseparable, distinguishable yet interconnected, subjects: mother and child. In

\footnotetext{
${ }^{24}$ See \#12 above in which Bostic addresses the criticism on the part of previous readers of Irigaray, that her recent work is heterosexist, a charge which Bostic claims is the result of "assumptions embedded in the ways some readers fill in the gaps in her discourse" (Bostic 604). Irigaray is speaking about strategic, cultural relations and not sexual relations.
} 
this way, we not only free the mother to be a subject-in-her-own-right, but we also free ourselves, her daughters and her sons, to evolve different grounds for loving relations. ${ }^{25}$

The kill-or-be-killed paradigm that is integral to Western hierarchical/oppositional thought which has cast the maternal-feminine outside discourse as its denigrated other, has left us without a model for loving-within-difference. A life-giving logic of difference which I have referred to as $a(m)$ other logic (of love) was foreclosed as she was not there to set a limit to an abstracted, body/mind severing logic.

Love is refigured as thriving in the threshold between two. If there is no real relation of difference, the chances for the emergence of love are greatly diminished and even foreclosed. In this foreclosure, we find the dereliction of love relations, reduced to prosthetic and/or sacrificial dynamics. Sacrificial logic and relations began as an error in which a discursive war was waged against the maternal-feminine-other rather than being articulated from within $a(m)$ other logical relation-of-connection-in-difference with her, and arising from the bi-unity of her consubstantiality as both nature and culture.

The corporeal culture found in maternal relations, both in the placental-chimeric dynamic, and that of differences in engendering between males and females, opens to levels of difference that have yet to be languaged.

The logic of the placental-chimeric relation represents the primordial, natural-corporeal culture, from which a revolutionary hermeneutic of love may be thought. Not only does it embody the first mode of differentiation, between self and other, but it also offers a new discourse for thinking the ternary space of two subjects whose becoming is intertwined.

$A(m)$ other logic, grounded in corporeal culture has the potential to transmute male envy of women's procreative potential, as well as the insecurity that can accompany a fantasy of originary fusion with an all-powerful maternal-feminine. Further, the fact that the gift of life can be understood as one of mutual exchange within the placental-fetal-chimeric relation provides a corporeal corrective to the fantasy that it is only the mother who gives life.

Apperson (2017) reflects upon the need to create a culture of love grounded in difference when he claims that we "must create a space and time to listen and understand the other and at the same time recognize that one can never fully understand the other and therefore can never colonize the other. The other is and must remain a mystery" (n.p.). It is within the mystery of this threshold, created and sustained within the middle/third space co-created with the other who is different, that holds the potential for the emergence of $a(m)$ other logic (of love) to originate in Western culture.

\footnotetext{
${ }^{25}$ Likewise, Oliver (2010), in a review of feminist theorizing regarding "motherhood debates" over the past few decades notes "the maternal body with its other-within not only challenges traditional theories of personal identity, but also can be taken up as the beginning of a new ethics of difference" (763).
} 


\section{References}

Apperson, N. Personal interview. May 14, 2017.

Baraitser, L. (2009). Maternal encounters: The ethics of interruption. London: Routledge.

Barfield, O. (1988). Saving the appearances: A Study in idolatry (2nd ed.). Middletown, CT: Wesleyan University Press.

Bayne, E. (2011). Womb envy: The Cause of misogyny and even male achievement? Women's Studies International Forum, 34, 151-160. www.elsevier.com, doi:10.1016/j.wsif.2011.01.007.

Benjamin, J. (2005). What mothers and babies need: The maternal third and its presence in clinical work. In S.F. Brown (Ed.), What do mothers want? Developmental perspectives, clinical challenges (pp. 37-54). Hillsdale, NJ: Analytic Press.

Birksted-Breen, D. (1996). Unconscious representations of femininity. Journal of the American Psychoanalytic Association, 44, 119-132.

Bostic, H. (2002). Luce Irigaray and love." Cultural Studies, 16(5), 603-610. http://www.tandf.co.uk/journals, doi:10.1080/0950238022000025219.

Coelho, N. (2015). The Origins and destinies of the idea of thirdness in contemporary psychoanalysis. International Journal of Psychoanalysis, 97(4), 1105-1127.

Cornford, F. M. (1991). From religion to philosophy: A Study in the origins of Western speculation. Princeton, $\mathrm{NJ}$ : Princeton University Press.

Elise, D. (1997). Primary femininity, bisexuality, and the female ego ideal: A Re-Examination of female developmental theory. Psychoanalytic Quarterly, 66, 489-517.

Fannin, M. (2014). Placental relations. Feminist Theory, 15(3), 289-306.

Ferguson, A. (2017). Love as a political force: Romantic love, love-politics and solidarity. In R. Grossi and D. West (Eds.), The Radicalism of romantic love: Critical perspectives (pp. 9-29). New York: Routledge.

Ferguson, A. \& Toye, E. (2017). Introduction, Feminist Love Studies, Hypatia, 32(1), 5-18.

Garcia-Andrade, A., Gunnarasson, L. \& Jonasdottir, A. D. (Eds.), (2018). Feminism and the Power of Love, London and New York: Routledge.

Gunnarsson, L. (2014) The Contradictions of love: Toward a feminist-realist ontology of sociosexuality. New York: Routledge.

Irigaray, L. (1985a). Speculum of the other woman. Translated by Gillian C. Gill. Ithaca, NY: Cornell University Press.

Irigaray, L. (1985b). This Sex which is not one. (C. Porter \& C. Burke, Trans.). Ithaca: Cornell University Press. Irigaray, L. (1991). The Irigaray reader. M. Whitford (Ed.). London: Blackwell Publishers.

Irigaray, L. (1993). Je, tu, nous: Toward a culture of difference. (A. Martin, Trans.). New York and London: Routledge.

Irigaray, L. (2004). L. Irigaray (Ed.). Luce Irigaray: Key Writings. London: Continuum.

Irigaray, L. (2008). Conversations. London: Continuum.

Irigaray, L. (2013). In the beginning, she was. London: Bloomsbury.

Jaspers, K. (1953). The Origin and goal of history. New Haven, CT: Yale University Press.

Jones, R. (2011). Irigaray: Towards a sexuate philosophy. Cambridge, UK: Polity Press.

Jordan, N. (2017). Placental thinking. In Placenta wit: Stories, rituals, and research. N. Jordan (Ed.), Bradford, Ontario: Demeter Press.

Keller, C. (1986). From a broken web: Separation, sexism, and self. Boston: Beacon Press.

Kelly, S. E. (2012, June). The Maternal-Foetal interface and gestational chimerism: The emerging importance of chimeric bodies. Science as Culture, 21(4), 233-257.

Kirby, V. (2008). Natural convers(at)ions: Or, what if culture was really nature all along? In S. Alaimo \& S. Hekman (Eds.), Material Feminisms (pp. 214-236). Bloomington: Indiana University Press.

Kittay, E. F. (1984a). Rereading Freud on 'femininity' or Why not womb envy? Women's Studies International Forum, (7) 5, 385-391.

Kittay, E. F. (1984b). Womb envy: An Explanatory concept. In J. Trebilcot (Ed.) Mothering: Essays in feminist theory (pp. 94-128). Totowa, N.J: Rowman \& Allanheld. 
Lacan, J. (1975). The Seminar of Jacques Lacan, Book I, 1953-1954. (J. Forrester, Trans.), New York: Norton.

Lawler-Lynch, C. (2011). Orestes with Oedipus: Psychoanalysis and matricide. In M. Rawlinson, S. L. Hom, \& S. J. Khader (Eds.), Thinking with Irigaray (pp. 13-38). Albany, New York: State University of New York Press.

Lawler-Lynch, C. (2016). Desire at the threshold: 'Vulvar logic' and intimacy between two. In M. Rawlinson, (Ed.), Engaging the world: Thinking after Irigaray (pp. 233-264). Albany, New York: State University of New York Press.

Lynch-Lawler, C. (2019a). Plato's creative imagination: (Re)Membering the chora(I) love that we are. Feminist Theology, 28(1), 104-123.

Lynch-Lawler, C. (2019b). From Oppositional consciousness to participation in a ternary logic of love: Embodying the third space that we are (Unpublished doctoral dissertation). California Institute of Integral Studies, San Francisco, CA.

Lynch-Lawler, C. (2020). "The Re-Enchanted garden: Participatory sentience and becoming-subject in 'third space."' In G. Schwab (Ed.), Thinking life with Luce Irigaray: Reconsidering nature, art, love, and democracy in the 21st Century, (pp. 39-60). Albany: State University of New York Press.

Lynch-Lawler (Forthcoming, June 2021). Healing foundational wounds between mothers and sons: From Womb envy to asymmetrical generativity. In Global Perspectives on Mothering, Motherhood and Masculinities, T. O. Pearce \& A. Moraes (Ed.). Bradford, Ontario: Demeter Press.

Marcus, B. (2004). Female passion and the matrix of mother, daughter, and body: Vicissitudes of the maternal transference in the working through of sexual inhibitions. Psychoanalytic Inquiry, 24(5) 2004, 680-712.

Martin, A. (2010). Microchimerism in the mother(land): Blurring the borders of body and Nation. Body and Society, 16(3), 23-50. DOI: 10.1177/1357034X10373404

Mathews, F. (1989). Some reflections on Spinoza's theory of substance. Philosophia, 19(1), 3-21.

Ogden, T. (2004). "The Analytic third: Implications for psychoanalytic treatment and practice." The Psychoanalytic Quarterly 73(1) (January): 167-195.

Ogden, T. (1994). Subjects of Analysis. Northvale, NJ: Aronson.

Oliver, K. (2010). Motherhood, sexuality, and pregnant embodiment: Twenty-five years of gestation." Hypatia, 25(4), 760-777.

Oliver, K. (1998). Subjectivity without subjects: From abject fathers to desiring mothers. Lanham, MD: Rowman \& Littlefield.

O'Reilly, A. (2016). Matricentric feminism. Bradford, Ontario: Demeter Press.

Plato. (2016). Timaeus. (P. Kalkavage, Trans.) (2nd ed.). Indianapolis: Hackett Publishing.

Plumwood, V. (1993). Feminism and the mastery of nature. New York and London: Routledge.

Roberts, L. (2017). A Revolution of love: Thinking through a dialectic that in not 'one.' Hypatia, 2(1), 69-85.

Rose, J. (1996). Of knowledge and mothers: On the work of Christopher Bollas. Gender and Psychoanalysis, 1(4), 411-428.

Sampson, K. (2013). Soma, techne and the somatechnics of sexual difference." Somatechnics, 3, 233-249.

Sandler, L. (2002). Thinking differently: Principles of process in living systems and the specificity of being known. Psychoanalytic Dialogues, 2(1), 11-42.

Sandoval, C. (2000). Methodology of the oppressed. Minneapolis: University of Minnesota Press.

Schwab, G. (1994). Mothers body, father's tongue: Mediation and the symbolic order. In C. Burke, N. Schor, \& M. Whitford, (Eds.). Engaging with Irigaray (pp. 351-378). New York: Columbia University Press.

Steiner, R. (1985). Goethe's world view. New York: Mercury Press.

Stone, A. (2012). Feminism, psychoanalysis, and maternal subjectivity. New York and London: Routledge.

Vaughan, G. (2015). The Gift in the heart of language: The maternal source of meaning. Mimesis International.

Walker, M. B. (1998). Philosophy and the maternal body: Reading silence. New York and London: Routledge.

Wheelwright, P., ed. (1997). The Presocratics. Upper Saddle River, NJ: Prentice-Hall.

Weiland, C. (2000). The Undead mother: Psychoanalytic explorations of masculinity, femininity, and matricide. London: Rebus.

Winnicott, D. W. (1971). Playing and reality. London: Tavistock Publications. 